\section{Characterization of resistance genes to macrolides, lincosamides and streptogramins (MLS) among clinical isolates of Staphylococcus aureus in North Lebanon}

\section{Abstract}

Objective: Staphylococcus aureus is one of the most significant pathogens causing significant morbidity and mortality. Moreover, the incidence of MLS S. aureus (resistant at least for one macrolide) infections continues to grow globally. The aim of this study is to examine the expression of resistance of $S$. aureus isolates to MLS and the prevalence of genes involved in this resistance using PCR.

Methods: A total 38 strains of S. aureus MLS-resistant were isolated in the Microbiology Labs at Nini Hospital in North Lebanon. The disk diffusion method was used to determine the phenotype of the MLS resistance. The resistance genes involved were detected by PCR using specific gene primers for ermA, ermB, ermC, msrA, $\operatorname{lin} A$, mefA, vat and vgb genes.

Results: A total of $55.3 \%$ of the isolates were positive for inducible phenotype ( $\mathrm{iMLS}_{\mathrm{B}}$ ), of these $15.8 \%$ were positive for the constitutive phenotype $\left(\mathrm{CMLS}_{B}\right), 23.7 \%$ for $\mathrm{MS}_{B}$ phenotype and $5.2 \%$ for $\mathrm{L}$ phenotype. The ermC gene was the most prevalent (52.6\%), while ermA, ermB, msrA and linA genes were observed with lower prevalence. A combination of several of these genes was detected, whereas the $v g b$, vat and mefA genes were not detected in any of the clinical isolates.

Conclusion: This study is the first investigated characterization of MLS resistance genes in clinical isolates of $S$. aureus in Lebanon according to
Marwan Osman ${ }^{1,2}$, Azza Al Nasbeh ${ }^{1,2}$, Rayane Rafei $^{1,2}$, Hassan Mallat ${ }^{1,2}$, Marcel Achkar ${ }^{3}$, Fouad Dabboussi ${ }^{1}, 2$, Monzer Hamze ${ }^{1,2}$

1 Centre AZM pour la recherche en biotechnologies et ses applications, Université Libanaise, Laboratoire de Microbiologie Santé et Environnement (LMSE), Tripoli, Lebanon.

2 Faculty of Public Health, Lebanese University, Lebanon

3 Clinical Laboratory, Nini Hospital, Tripoli, Lebanon

Corresponding author:

Prof. Dr. Monzer Hamze

” mhamze@monzerhamze.com 
our knowledge. The study revealed a high prevalence of the inducible resistance to lincosamides (iMLS $\mathrm{B}_{B}$ phenotype) and the most prevalent resistance determinants was erm $C$.

Keywords: Staphylococcus aureus, Macrolides, Antimicrobial resistance, ermC, msrA, Lebanon

\section{Introduction}

Macrolides have been known for more than six decades, and, since the introduction of erythromycin molecule into therapy, a number of these antibiotics have been developed for clinical use. For years, these drugs have represented a major alternative of beta-lactams for the treatment of infections caused by gram-positive bacteria such as B-hemolytic Streptococci, Streptococcus pneumoniae and Staphylococcus aureus. Macrolides, lincosamides and streptogramines (MLS) are related molecules, with similar antibacterial spectrum and mechanisms, but with different chemical structure.The use of these antibiotics has been accompanied by the rapid appearance of resistant strains in staphylococci $[1,2]$. Various resistance mechanisms have been described to these antimicrobials including ribosomal target modification by single mutation or methylation of 23SrRNA gene, modification of the drug, and efflux pumps [3]. However, the predominant mechanism in staphylococci resistance is target modification mediated by ermA, ermB and ermC (erythromycin ribosome methylase genes) $[1,3]$.

Several common genes responsible for resistance to macrolide, lincosamide and streptogramin $B\left(M_{B}\right)$ antibiotics were reported. The erm genes encode enzymes that confer inducible $\left(\mathrm{iMLS}_{\mathrm{B}}\right)$ or constitutive $\left(\mathrm{CMLS}_{B}\right)$ resistance to $\mathrm{MLS}_{B}$ antibiotics via methylation of a single adenine in the $23 \mathrm{~S}$ rRNA gene, thereby reducing binding by $\mathrm{MLS}_{\mathrm{B}}$ antibiotics to the 50S large subunit of the ribosome [4]. Another fairly common mechanism of macrolide resistance were reported in $S$. aureus and mediated by two important efflux genes, msrA (macrolide efflux) and mefA (macrolide efflux protein A) genes, which confer only resistance to macrolide and streptogramin $B\left(\mathrm{MS}_{\mathrm{B}}\right)$ antibiotics $[3,5]$. The msrA gene encodes a 488-amino-acid ATP-binding cassette $(A B C)$ transporter hydrophilic protein that contains two ATP-binding motifs characteristic of the $A B C$ transporters. However, the mefA gene is a proton motive force-driven efflux pump involved in resistance to $\mathrm{MS}_{\mathrm{B}}$ antibiotics $[3,5,6]$. Moreover, hydrolysis of antibiotics through the activity of esterases and/or phosphotransferaseshas only been reported in staphylococci [3].

Resistance to $\mathrm{MLS}_{\mathrm{B}}$ among S. aureus is an increasing problem. The overlapping binding sites of $M L_{B}$ in 235 rRNAcauses cross-resistance to the three classes of antibiotics. A wide range of bacterial pathogens that are targets for $\mathrm{MLS}_{\mathrm{B}}$ express Ermmethylases.The new nomenclature system distinguishes 21 classes of erm genes and as many corresponding Erm proteins with predominance of ermA, ermB and erm $C$ in staphylococcal gene classes [2,3]. In bacterial pathogens, these determinants are mainly carried by plasmids and transposons that are self-transferable. The ermA gene is often harbored on the transposon Tn554 which has been described as predominantly having a single specific site for insertion in the $S$. aureus chromosome $[7,8]$. Furthermore, the ermB 
gene is mostly associated on transposon Tn551 and the penicillinase plasmid (pl258) [9,10]. However, the ermC gene is normally found on small plasmids ranging in size from 2.4 to $5 \mathrm{~kb}$ [4].

Other resistance mechanisms to MLS were reported. The O-nucleotidyltransferases encoded in S. aureus by lincosamide inactivation nucleotidylation (lin)genes, confer resistance to lincomycin but not to clindamycin (L phenotype)[1,11,12]. The staphylococcal vat genes confer resistance to streptogramin $A$ and similar compounds by acetylation of the antibiotics. In addition, the staphylococcal vga genes encode related ATP-binding proteins probably involved in the active efflux of $A$ compounds $[13,14]$.

This study aimed to investigate the epidemiology of MLS resistance in Lebanon, particularly prevalence of MLS resistance phenotypes and molecularly characterize the macrolide resistance genes in clinical strains of $S$. aureus isolated from patients in North Lebanon.

\section{Material and Methods}

\section{Sample collection}

Thirty-eightS. aureus MLS-resistant isolates were collected from patients in Nini hospital. All isolates were transported immediately to the Health and Environmental Microbiology Laboratory strain bank, in theAZM center for research in biotechnology, doctoral school, Lebanese University in Tripoli.

\section{Antimicrobial susceptibility test}

The susceptibility to antibiotics was performed by the disk diffusion method on Muller-Hinton agar (Bio-Rad, France) according to CLSI (Clinical and Laboratory Standards Institute) and (A-SFM 2015 (Comité de l'Antibiogramme de la SociétéFrançaise de Microbiologie 2015) recommendations.

MLS resistance phenotypes were performed using D-test with the following antibiotics: Erythromycin (15UI), lincomycin $(15 \mu \mathrm{g})$,spiramycin $(100 \mu \mathrm{g})$ and pristinamycin $(15 \mu \mathrm{g})$.

\section{DNA extraction and molecular identification of resistance genes}

All S. aureus strains were tested for detection of macrolide resistance genes. DNA was extracted using the GenElute ${ }^{\mathrm{TM}}$ Bacterial Genomic DNA (Sigma Aldrich ${ }^{\circledR}$,England), according to the manufacturer's recommended procedures. The DNA was eluted in $200 \mu \mathrm{l}$ of elution buffer and stored at $-20^{\circ} \mathrm{C}$ until use. All genes known to be responsible for S.aureus resistance to beta-lactams (mecA) and MLS (ermA, ermB, erm, , msrA, mefA, vat, vgb, and linA genes) were detected using PCR and primers specific to each gene (Table 1). Purified bacterial DNA from control strains and deionized water were respectively used as positive and negative control in each PCR run.

\section{Statistical analyses}

Statistical analyses were performed with GraphPad Prism 6.0 (GraphPad Software Inc., San Diego, CA) using the Fisher's exact test to explore the association between resistance to MLS and resistance to beta-lactams. The general significance level was set at a P-value below 0.05 .

\section{Results}

The percentage of susceptibility of all S.aureus isolates is showed in Table $\mathbf{2}$. Resistance to betalactams was found in 28/ 38 (73.7\%) strains using the disk diffusion method and PCR targeting mecA gene. MLS resistance phenotypes were determined by with D-test showed that among 38MLS-resistant isolates, 27 (71.1\%) exhibited the $\mathrm{MLS}_{\mathrm{B}}$ phenotype: 6 $(15.8 \%)$ belonged to the $\mathrm{CMLS}_{B}$, and $21(55.3 \%)$ to the $\mathrm{iMLS}_{\mathrm{B}}$ phenotype. The remaining 11 isolates (28.9 \%) were confirmed as $\mathrm{MS}_{B}(23.7 \%)$ and $\mathrm{L}$ (5.2\%) phenotypes (Table 3). No significant association between resistance to MLS and resistance to betalactams was found (Fisher's exact test, $p$-value $=0.6$ ).

In addition, PCR analysis targeting macrolide resistance genes showed that all $\mathrm{iMLS}_{\mathrm{B}}$ and $\mathrm{CMLS}_{\mathrm{B}}$ 
Table 1. Primers and PCR conditions used to detect the resistance genes.

\begin{tabular}{|c|c|c|c|c|}
\hline Gene & Primer sequence $\left(5^{\prime}-3^{\prime}\right)$ & $\begin{array}{l}\text { Size } \\
\text { (bp) }\end{array}$ & Reference & Protocol cycle \\
\hline mecA & $\begin{array}{l}\text { F. GTAGAAATGACTGAACGTCCGATAA } \\
\text { R. CCAATTCCACATTGTTTCGGTCTAA }\end{array}$ & 310 & [15] & $\begin{array}{c}35 \text { cycles }\left(30 \text { s at } 95^{\circ} \mathrm{C} ; 45 \text { s at } 50^{\circ} \mathrm{C} ; 30\right. \\
\left.\text { sat } 72^{\circ} \mathrm{C}\right) ;\end{array}$ \\
\hline ermA & $\begin{array}{l}\text { F. AAGCGGTAAACCCCTCTGA } \\
\text { R. TTCGCAAATCCCTTCTCAAC }\end{array}$ & 190 & [16] & $\begin{array}{c}30 \text { cycles }\left(30 \mathrm{~s} \text { at } 94^{\circ} \mathrm{C} ; 30 \mathrm{~s} \text { at } 52^{\circ} \mathrm{C} ; 1\right. \\
\left.\text { min at } 72^{\circ} \mathrm{C}\right)\end{array}$ \\
\hline ermB & $\begin{array}{l}\text { F. CTATCTGATTGTTGAAGAAGGATT } \\
\text { R. GTTTACTCTTGGTTTAGGATGAAA }\end{array}$ & 142 & [16] & Same as ermA \\
\hline ermC & $\begin{array}{l}\text { F. AATCGTCAATTCCTGCATGT } \\
\text { R. TAATCGTGGAATACGGGTTTG }\end{array}$ & 299 & [16] & Same as ermA \\
\hline $\operatorname{lin} A$ & $\begin{array}{l}\text { F. GGTGGCTGGGGGGTAGATGTATTAACTGG } \\
\text { R. GCTTCTTTTGAAATACATGGTATTTTTCGATC }\end{array}$ & 323 & [17] & $\begin{array}{c}30 \text { cycles }\left(30 \mathrm{~s} \text { at } 94^{\circ} \mathrm{C} ; 30 \mathrm{~s} \text { at } 57^{\circ} \mathrm{C} ; 1\right. \\
\left.\text { min at } 72^{\circ} \mathrm{C}\right)\end{array}$ \\
\hline Vat & $\begin{array}{l}\text { F. CAATGACCATGGACCTGATC } \\
\text { R. CTTCAGCATTTCGATATCTCC }\end{array}$ & 619 & [16] & Same as ermA \\
\hline$V g b$ & $\begin{array}{l}\text { F. ACTAACCAAGATACAGGACC } \\
\text { R. TTATTGCTTGTCAGCCTTCC }\end{array}$ & 734 & [17] & $\begin{array}{l}30 \text { cycles }\left(1 \mathrm{~min} \text { at } 94^{\circ} \mathrm{C} ; 1 \mathrm{~min} \text { at } 53^{\circ} \mathrm{C} \text {; }\right. \\
\left.\qquad 2 \min \text { at } 72^{\circ} \mathrm{C}\right) ;\end{array}$ \\
\hline msrA & $\begin{array}{l}\text { F. GGCACAATAAGAGTGTTTAAAGG } \\
\text { R. AAGTTATATCATGAATAGATTGTCCTGTT }\end{array}$ & 940 & [17] & $\begin{array}{c}25 \text { cycles }\left(1 \mathrm{~min} \text { at } 94^{\circ} \mathrm{C} ; 1 \mathrm{~min} \text { at } 50^{\circ} \mathrm{C} \text {; }\right. \\
\left.90 \mathrm{~s} \text { at } 72^{\circ} \mathrm{C}\right) ;\end{array}$ \\
\hline mefA & $\begin{array}{l}\text { F. AGTATCATTAATCACTAGTGC } \\
\text { R. TTCTTCTGGTACTAAAAGTGG }\end{array}$ & 348 & [18] & $\begin{array}{c}35 \text { cycles }\left(30 \mathrm{~s} \text { at } 94^{\circ} \mathrm{C} ; 30 \mathrm{~s} \text { at } 50^{\circ} \mathrm{C} ; 90\right. \\
\left.\text { s at } 72^{\circ} \mathrm{C}\right)\end{array}$ \\
\hline
\end{tabular}

Table 2. Percentage of sensitivity of thirty-eight S. aureusisolates

\begin{tabular}{|c|c|c|c|}
\hline Antibiotic (disk charge) & $\begin{array}{c}\% \text { of } \\
\text { susceptible }\end{array}$ & Antibiotic (disk charge) & $\begin{array}{c}\% \text { of } \\
\text { susceptible }\end{array}$ \\
\hline Fusidic acid $(10 \mu \mathrm{g})$ & $76.3 \%$ & Novobiocin $(5 \mu \mathrm{g})$ & $89.2 \%$ \\
\hline $\begin{array}{l}\text { Amoxicillin/clavulanic acid } \\
\qquad(20 / 10 \mu \mathrm{g})\end{array}$ & $26.3 \%$ & Oxacillin $(5 \mu g)$ & $26.3 \%$ \\
\hline Cefoxitin $(30 \mu \mathrm{g})$ & $26.3 \%$ & Ciprofloxacin $(5 \mu \mathrm{g})$ & $34.2 \%$ \\
\hline Chloramphenicol (30 ㅆg) & $94.7 \%$ & Pristinamycin $(15 \mu \mathrm{g})$ & $97.4 \%$ \\
\hline Erythromycin $(15 \mu \mathrm{g})$ & $5.2 \%$ & Rifampicin $(30 \mu \mathrm{g})$ & $94.6 \%$ \\
\hline Fosfomycin $(50 \mu \mathrm{g})$ & $92.1 \%$ & Spiramycin $(100 \mu \mathrm{g})$ & $57.9 \%$ \\
\hline Gentamicin $(15 \mu \mathrm{g})$ & $78.9 \%$ & Teicoplanin $(30$ нg) & $100 \%$ \\
\hline Kanamycin $(30 \mu \mathrm{g})$ & $71.1 \%$ & Tetracycline $(30 \mu \mathrm{g})$ & $78.9 \%$ \\
\hline Lincomycin $(15 \mu \mathrm{g})$ & $76.3 \%$ & Tigecycline $(15 \mu \mathrm{g})$ & $97.4 \%$ \\
\hline Linézolid $(30$ g) & $100 \%$ & Tobramycin $(10 \mu \mathrm{g})$ & $76.3 \%$ \\
\hline Minocycline $(30 \mu \mathrm{g})$ & $97.3 \%$ & Trimethoprim/sulfamethoxazole $(1,25 / 23,75 \mu \mathrm{g})$ & $81.6 \%$ \\
\hline Nitrofuran $(300 \mu \mathrm{g})$ & $100 \%$ & Vancomycin $(30 \mu \mathrm{g})$ & $100 \%$ \\
\hline
\end{tabular}

strains harbored at least the erm $C$ gene, exceptthree $\mathrm{iMLS}_{\mathrm{B}}$ isolates that did not carry any of the tested genes.The $\mathrm{MS}_{B}$ isolates carried ermA gene (1/9), mrsA gene (5/9), both ermA and ermC genes (1/9) and both erm $C$ and $m r s A$ genes (2/9). The two $L$ isolates carried linA and both linA and mrsA respectively.On the other hand, $m e f A$, vat andvgb genes were not detected in any of the isolates (Table 4). 
Table 3. The MLS phenotypes of resistance detected for S. aureus isolates.

\begin{tabular}{|c|c|c|c|c|c|}
\hline Phenotype & iMLS $_{\mathbf{B}}(\%)$ & CMLS $_{\mathbf{B}}$ (\%) & MS $_{\mathbf{B}}$ (\%) & L (\%) & Total no. (\%) \\
\hline MRSA & $16(42.1 \%)$ & $5(13.2 \%)$ & $5(13.2 \%)$ & $2(5.2 \%)$ & $28(73.7 \%)$ \\
\hline MSSA & $5(13.2 \%)$ & $1(2.6 \%)$ & $4(10.5 \%)$ & $0(0 \%)$ & $10(26.3 \%)$ \\
Total & $21(55.3 \%)$ & $6(15.8 \%)$ & $9(23.7 \%)$ & $2(5.2 \%)$ & $38(100 \%)$ \\
\hline
\end{tabular}

Table 4. Correlation between genotypes and phenotypes for MLS resistance for $\mathrm{S}$. aureusisolates

\begin{tabular}{|c|c|c|c|c|c|c|c|c|c|c|}
\hline \multirow{2}{*}{ Phenotype } & \multicolumn{10}{|c|}{ Genotype } \\
\hline & ermA & ermC & $\begin{array}{l}\text { ermB/ } \\
\text { ermC }\end{array}$ & $\begin{array}{l}\text { ermA/ } \\
\text { ermC }\end{array}$ & $\begin{array}{c}\text { ermB/ermCl } \\
\text { mrsA }\end{array}$ & $\begin{array}{l}\text { ermCl } \\
\text { mrsA }\end{array}$ & mrsA & $\operatorname{lin} A$ & $\begin{array}{l}\operatorname{lin} A / \\
\text { mrsA }\end{array}$ & NI \\
\hline $\mathrm{iMLS}_{\mathrm{B}}$ & 0 & 15 & 1 & 1 & 1 & 0 & 0 & 0 & 0 & 3 \\
\hline $\mathrm{CMLS}_{\mathrm{B}}$ & 0 & 5 & 0 & $1^{\mathrm{a}}$ & 0 & 0 & 0 & 0 & 0 & 0 \\
\hline $\mathrm{MS}_{\mathrm{B}}$ & 1 & 0 & 0 & 1 & 0 & 2 & 5 & 0 & 0 & 0 \\
\hline L & 0 & 0 & 0 & 0 & 0 & 0 & 0 & 1 & 1 & 0 \\
\hline
\end{tabular}

aPristinamycin-resistant strain ; No.I was non-identified genotype.

\section{Discussion}

The resistance to antibiotics among $\mathrm{S}$. aureus is an increasing problem, both in hospitals and communities of most Arab Middle East countries. A recent review by Tokajian et al. [19] on the epidemiology of $\mathrm{S}$. aureus in these countries showed wide genetic change due to the introduction of new clones from other countries. Moreover, a previous study conducted in the same geographic region, demonstrated that methicilli-nresistant $\mathrm{S}$. aureus (MRSA) strains colonizing infants carried 1-3 clinically important staphylococcal toxin genes [20]. In Lebanon, a recent study on antimicrobial susceptibility patterns of $\mathrm{S}$. aureus clinical isolates revealed that only $56 \%$ were susceptible to all tested antibiotics [21]. In addition, the prevalence of MRSA infection are also increased in Lebanon in the last decade $[22,23]$.These reports have led to renewed interest in the usage of MLS to treat staphylococcal infections [24]. Clindamycin is now a good alternative in the treatment of infections due to S. aureus, particularly MRSA isolates and as an alternative in penicillin-allergic patients. However, clindamycin resistance can be developed rapidly in S. aureus strains, and constitutive resistant mutants have arisen both in vitro testing and in vivo clinical therapy $[25,26]$.

The CLSI and CA-SFM 2015 guidelines for disk diffusion susceptibility recommend the use of D-test to detect the inducible clindamycin resistance (iMLS phenotype), and suggest that $\mathrm{S}$. aureus isolates with the $\mathrm{iMLS}_{\mathrm{B}}$ phenotype should be reported as clindamycin-susceptible, but associated with clinical failures possibility related to the selection of clindamycin-resistant mutants.

A total of $38 \mathrm{~S}$. aureus clinical isolates were examined. Firstly, according to the D-test screening, the $\mathrm{iMLS}_{\mathrm{B}}$ phenotype was the most predominant resistant phenotype (55.3\%). These findings were different from the results obtained in a study conducted amongs. aureus isolates in Turkey, whereby the $\mathrm{CMLS}_{\mathrm{B}}$ phenotype was the predominant resistance phenotype (63\%) [27]. Otherwise, we reported a similar distribution of MLS resistance phenotypes to that described in the UK by Hamilton-Miller et al.[28]. However, various studies conducted in Turkey [27], Europe [29], Japan 
[30]Colombia [31], and France [17], reported that the $\mathrm{iMLS}_{\mathrm{B}}$ and $\mathrm{CMLS}_{\mathrm{B}}$ phenotypes were predominant in methicillin-susceptible $S$. aureus (MSSA) and MRSA isolates, respectively. However, may be due to the low number of examined $\mathrm{S}$. aureus strains in this study, we could not find any association between MLSresistance phenotypes and resistance to betalactams.

Secondly, it has reported that accurate and rapid determination of antimicrobial resistance genes will help to select the proper the treatment of $S$. aureus infections and to avoide the spread of resistant genes [32,33]. Overall, 36 / 38 of the examined strains were resistant to erythromycin, of these, 91.6\% had at least one of these genes:ermA, ermB, ermC and/ormsrA. These results are similar to those reported by Martinau et al. [34] who demonstrated the same findings among $\mathrm{S}$. aureus strains resistant to erythromycin. However, 3 of those isolates did not carry any of the tested genes.These results were probably associated with the presence of other genes with low frequency in S. aureus, which were not evaluated in our investigation [33]. Also, this study found that efflux genes such as msrA gene was present either alone or in association with other genes $(23.7 \%)$, while the mefA gene was absent from all tested isolates. These results concur with those described by Zmantar et al. [35], who reported the same observation. Furthermore, we found a predominance of ermC gene (27/38) among MLS resistance genes. The ermC gene was described to be the predominant MLS resistance gene in S. aureus isolates in Greece [36]. On the other hand, the ermA gene was detected alone in one isolate, and in association with erm $\mathrm{C}$ gene in 3 isolates of S. aureus, while a Colombian investigation reported that $100 \%$ of MRSA resistant to erythromycin had the $\mathrm{CMLS}_{\mathrm{B}}$ resistance phenotype and harbored the ermA gene [31]. In the same context, recent data from a multicenter study in Europe confirmed the predominance of ermA gene among S. aureus, while ermC and ermB genes were rarely detected [37]. Additionally, two isolates in our study harbored the linA gene. These results are also supported by recent findings, which showed that the linA gene was rarely detected in $\mathrm{S}$. aureus strains $[17,38,39]$.

Finally, all tested $S$. aureus strains, including methicillin resistant and MLS-resistant were susceptible to linezolid and vancomycin. Our data accord with a previous study conducted by Kanj et al. [40], in which good activity of these antibiotics was described against most Gram-positive pathogens from the Middle East and Africa.

In conclusion, to our best knowledge, this study is the first investigation regarding characterization of MLS resistance genes in clinical isolates of $\mathrm{S}$. aureus in Lebanon. Our data indicates a predominance of $\mathrm{iMLS}_{\mathrm{B}}$ phenotype and ermC gene in these isolates. Other genes ( ermA, ermB, msrA and $\operatorname{lin} A$ ) were found with lower prevalence. The epidemiological significance of this study remains to be confirmed by further testing large number of $\mathrm{S}$. aureus strains.

\section{Acknowledgements}

We would like to thank TahaAbdou and Mariam Yehya for their excellent technical assistance, Husam Khaled for thecritical readingof themanuscript, and Pr. Ghassan Matar from American University of Beirut for kindly providing us control strains. Both Marwan Osman and Azza Al Nasbeh have equally contributed in this paper.

\section{Funding}

This study was financed by the AZM center for research in biotechnology and its applications, Doctoral School of Science and Technology, Lebanese University, Tripoli, Lebanon. 


\section{Competing Interests}

The authors have declared that no competing interests exist.

\section{References}

1. Roberts MC, Sutcliffe J, Courvalin P, Jensen LB, Rood J, Seppala $\mathrm{H}$. Nomenclature for macrolide and macrolide-lincosamidestreptogramin B resistance determinants. Antimicrob Agents Chemother 1999; 43: 2823-2830.

2. Sanchez ML, Flint KK, Jones RN. Occurrence of macrolidelincosamide-streptogramin resistances among staphylococcal clinical isolates at a university medical center Is false susceptibility to new macrolides and clindamycin a contemporary clinical and in vitro testing problem? DiagnMicrobiol Infect Dis 1993; 16: 205-213.

3. Leclercq R. Mechanisms of resistance to macrolides and lincosamides: nature of the resistance elements and their clinical implications. Clin Infect Dis 2002; 34: 482-492.

4. Weisblum B. Erythromycin resistance by ribosome modification. Antimicrob Agents Chemother 1995; 39: 577-585.

5. Swenson JM, Brasso WB, Ferraro MJ, Hardy DJ, Knapp CC, McDougal LK, et al. Detection of inducible clindamycin resistance in staphylococci by broth microdilution using erythromycinclindamycin combination wells. J ClinMicrobiol 2007; 45: 39543957.

6. Clancy J, Petitpas J, Dib-Hajj F, Yuan W, Cronan M, Kamath $A V$, et al. Molecular cloning and functional analysis of a novel macrolide-resistance determinant, mefA, from Streptococcus pyogenes. MolMicrobiol 1996; 22: 867-879.

7. Murphy E. Nucleotide sequence of ermA, a macrolidelincosamide-streptogramin B determinant in Staphylococcus aureus. J Bacteriol 1985; 162: 633-640.

8. Tillotson LE, Jenssen WD, Moon-McDermott L, Dubin DT. Characterization of a novel insertion of the macrolideslincosamides-streptogramin B resistance transposon Tn554 in methicillin-resistant Staphylococcus aureus and Staphylococcus epidermidis. Antimicrob Agents Chemother. 1989; 33: 541-550.

9. Khan SA, Novick RP. Terminal nucleotide sequences of Tn551, a transposon specifying erythromycin resistance in Staphylococcus aureus: homology with Tn3. Plasmid 1980; 4: 148-154.

10. Westh H, Hougaard DM, Vuust J, Rosdahl VT. erm genes in erythromycin-resistant Staphylococcus aureus and coagulasenegative staphylococci. APMIS 1995; 103: 225-232.

11. Bozdogan B, Berrezouga L, Kuo MS, Yurek DA, Farley KA, Stockman BJ, et al. A new resistance gene, linB, conferring resistance to lincosamides by nucleotidylation in Enterococcus faecium HM1025. Antimicrob Agents Chemother 1999; 43: 925-929.

12. Leclercq R, Brisson-Noel A, Duval J, Courvalin P. Phenotypic expression and genetic heterogeneity of lincosamide inactivation in Staphylococcus spp. Antimicrob Agents Chemother. 1987; 31: 1887-1891.

13. Allignet J, Aubert S, Morvan A, el Solh N. Distribution of genes encoding resistance to streptogramin $\mathrm{A}$ and related compounds among staphylococci resistant to these antibiotics. Antimicrob Agents Chemother 1996; 40: 2523-2528.

14. Allignet J, Loncle V, Mazodier P, el Solh N. Nucleotide sequence of a staphylococcal plasmid gene, vgb, encoding a hydrolase inactivating the $B$ components of virginiamycin-like antibiotics Plasmid 1988; 20: 271-275.

15. McClure JA, Conly JM, Lau V, Elsayed S, Louie T, Hutchins W, et al. Novel multiplex PCR assay for detection of the staphylococcal virulence marker Panton-Valentine leukocidin genes and simultaneous discrimination of methicillin-susceptible from -resistant staphylococci. J ClinMicrobiol 2006; 44: 1141-1144.

16. Strommenger B, Kettlitz C, Werner G, Witte W. Multiplex PCR assay for simultaneous detection of nine clinically relevant antibiotic resistance genes in Staphylococcus aureus. J ClinMicrobiol 2003; 41: 4089-4094.

17. Lina G, Quaglia A, Reverdy ME, Leclercq R, Vandenesch F, Etienne J. Distribution of genes encoding resistance to macrolides, lincosamides, and streptogramins among staphylococci. Antimicrob Agents Chemother 1999; 43: 1062-1066.

18. Sutcliffe J, Grebe T, Tait-Kamradt A, Wondrack L. Detection of erythromycin-resistant determinants by PCR. Antimicrob Agents Chemother 1996; 40: 2562-2566.

19. Tokajan S. New epidemiology of Staphylococcus aureus infections in the Middle East.ClinMicrobiol Infect 2014; 20:624628.

20. Shehabi AA, Abu-Yousef R, Badran E, Al-Bakri AG, AbuQatouseh LF, Becker K. Major Characteristics of Staphylococcus aureus colonizing Jordanian infants. Pediatr Int 2013; 55:300-304.

21. Khalil W, Hashwa F, Shehabi A, Tokajian S. Methicillin-resistant Staphylococcus aureus ST80-IV clone in children from Jordan. DiagnMicrobiol Infect Dis 2012; 73: 228-230.

22. El Ayoubi MD, Hamze M, Mallat H, Achkar M, Dabboussi F. Glycopeptide intermediate Staphylococcus aureus andprevalence of the luk-PV gene in clinical isolates, in NorthernLebanon. Med Mal Infect 2014; 44: 223-228.

23. Kanj SS, Ghaleb PA, Araj GF. Glycopeptide and oxacillin activity against Staphylococcus aureus isolates at a tertiary care center in Lebanon. J Med Liban 2004; 52: 8-12.

24. Chambers HF, Deleo FR. Waves of resistance: Staphylococcus aureus in the antibiotic era. Nat Rev Microbiol. 2009; 7: 629641.

25. Prabhu K, Rao S, Rao V. Inducible Clindamycin Resistance in Staphylococcus aureus Isolated from Clinical Samples. J Lab Physicians 2011; 3: 25-27.

26. Deotale V, Mendiratta DK, Raut U, Narang P. Inducible clindamycin resistance in Staphylococcus aureus isolated from clinical samples. Indian J Med Microbiol 2010; 28: 124-126.

27. Adaleti R, Nakipoglu Y, Ceran N, Tasdemir C, Kaya F, Tasdemir $S$. Prevalence of phenotypic resistance of Staphylococcus aureus isolates to macrolide, lincosamide, streptogramin B, ketolid and linezolid antibiotics in Turkey. Braz J Infect Dis 2010; 14: 11-14.

28. Hamilton-Miller JM, Shah S. Patterns of phenotypic resistance 
to the macrolide-lincosamide-ketolide-streptogramin group of antibiotics in staphylococci. J AntimicrobChemother. 2000; 46: 941-949.

29. Schmitz FJ, Verhoef J, Fluit AC. Prevalence of resistance to MLS antibiotics in 20 European university hospitals participating in the European SENTRY surveillance programme. Sentry Participants Group. J AntimicrobChemother. 1999; 43: 783-792.

30. Otsuka T, Zaraket H, Takano T, Saito K, Dohmae S, Higuchi W, et al. Macrolide-lincosamide-streptogramin B resistance phenotypes and genotypes among Staphylococcus aureus clinical isolates in Japan. ClinMicrobiol Infect. 2007; 13: 325327

31. Reyes J, Hidalgo M, Diaz L, Rincon S, Moreno J, Vanegas N, et al. Characterization of macrolide resistance in Gram-positive cocci from Colombian hospitals: a countrywide surveillance. Int J Infect Dis. 2007; 11: 329-336

32. Fluit AC, Visser MR, Schmitz FJ. Molecular detection of antimicrobial resistance. ClinMicrobiol Rev 2001; 14: 836-871, table of contents.

33. Sekiguchi J, Fujino T, Saruta $K$, Konosaki $H$, Nishimura $H$, Kawana $A$, et al. Prevalence of erythromycin-, tetracycline-, and aminoglycoside- resistance genes in methicillin-resistant Staphylococcus aureus in hospitals in Tokyo and Kumamoto. Jpn J Infect Dis 2004; 57: 74-77.

34. Martineau F, Picard FJ, Lansac N, Menard C, Roy PH, Ouellette M, et al. Correlation between the resistance genotype determined by multiplex PCR assays and the antibiotic susceptibility patterns of Staphylococcus aureus and Staphylococcus epidermidis. Antimicrob Agents Chemother 2000; 44: 231-238.

35. Zmantar T, Chaieb K, Ben Abdallah F, Ben Kahla-Nakbi A, Ben Hassen A, Mahdouani K, et al. Multiplex PCR detection of the antibiotic resistance genes in Staphylococcus aureus strains isolated from auricular infections. Folia Microbiol (Praha) 2008; 53: 357-362.

36. Spiliopoulou I, Petinaki E, Papandreou P, Dimitracopoulos $\mathrm{G}$. erm $(\mathrm{C})$ is the predominant genetic determinant for the expression of resistance to macrolides among methicillinresistant Staphylococcus aureus clinical isolates in Greece. J AntimicrobChemother 2004; 53: 814-817.

37. Schmitz FJ, Sadurski R, Kray A, Boos M, Geisel R, Kohrer K, et al. Prevalence of macrolide-resistance genes in Staphylococcus aureus and Enterococcus faecium isolates from 24 European university hospitals. J AntimicrobChemother 2000; 45: 891894.

38. Cetin ES, Gunes H, Kaya S, Aridogan BC, Demirci M. Distribution of genes encoding resistance to macrolides, lincosamides and streptogramins among clinical staphylococcal isolates in a
Turkish university hospital. J Microbiollmmunol Infect 2010; 43: 524-529.

39. Monecke S, Ehricht R. Rapid genotyping of methicillin-resistant Staphylococcus aureus (MRSA) isolates using miniaturised oligonucleotide arrays. ClinMicrobiol Infect 2005; 11: 825-833.

40. Kanj S, Whitelaw A, Dowzicky M. In vitro activity of tigecycline and comparators against Gram-positive and Gram-negative isolates collected from the Middle East and Africa between 2004 and 2011. Int J Antimicrob Agents 2014; 43: 170-178.

\section{Comment on this article:}

\section{(f) $(B)$ in $8+S$. P}

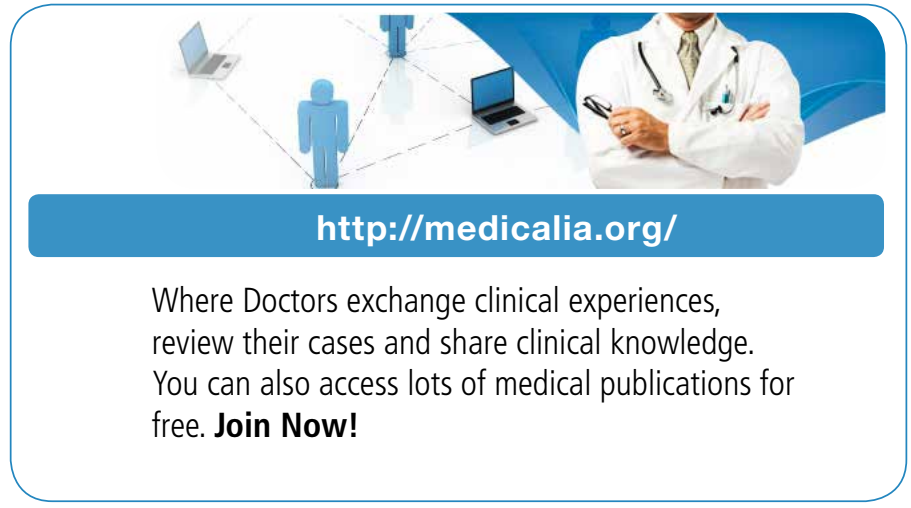

\section{Publish with iMedPub}

http://www.imed.pub

The Journal is an open access peer-reviewed journal that publishes scientific papers about all aspects of antimicrobials. The journal will publish original research articles, reviews, brief reports and case reports dealing with basic and clinical antibacterial agents, antiviral, antiprotozoals, antituberculuous, antifungal and antihelminthes agents.

All manuscripts must be prepared in English, and are subject to a rigorous and fair peer-review process. Accepted papers will immediately appear online.

The journal aims to advance the knowledge, attitude and the research of chemotherapy in the Arabic world in cooperation with international, national scientific and public societies as well as research centers with similar aims and objectives. 